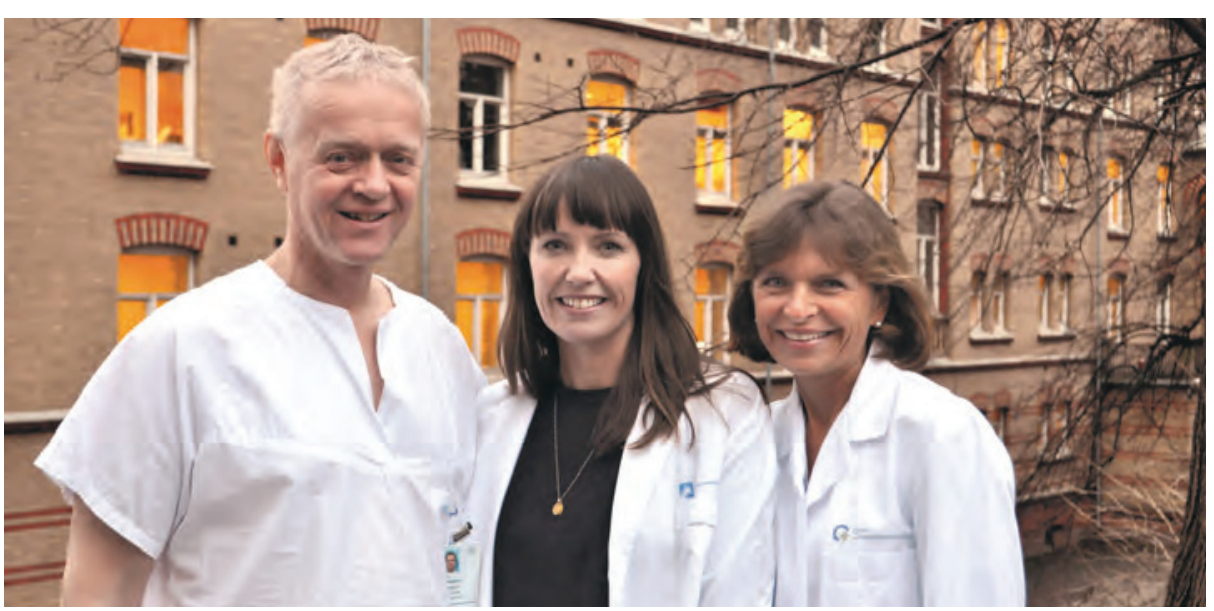

Lars Nordsletten, Ida Svege og May Arna Risberg. Foto: Privat

\section{Trening kan utsette behovet for hofteprotese}

Veiledet trening kan utsette behovet for hofteprotese hos pasienter med artrose. Dette viser en ny norsk studie.

Pasienter med hofteartrose med betydelig funksjonsnedsettelse og uttalte smerter blir ofte operert med innsetting av kunstig hofteledd. Det finnes ingen klare retningslinjer for når dette bør gjøres, men som regel blir pasientene operert etter noen år med tiltakende plager. I en norsk studie ble effekten av veiledet trening og pasientinformasjon på behovet for hofteprotese undersøkt (1).

Studien omfattet 109 pasienter med klinisk og røntgenologisk verifisert hofteartrose og milde til moderate symptomer. Ingen var kandidat for hofteprotese på inklusjonstidspunktet. Alle pasientene deltok på tre gruppesesjoner med pasientundervisning, og halvparten ble videre randomisert til 2-3 ukentlige treningsøkter med veiledning av fysioterapeut $i$ en 12-ukersperiode.

Seks år senere hadde 22 pasienter i treningsgruppen og 31 pasienter i kontrollgruppen gjennomgått hofteprotesekirurgi, hvilket gir en hasardratio på 0,56 (95\% KI $0,32-0,96)$. Median tid til protesekirurgi var 5,4 år i treningsgruppen og 3,5 år i kontrollgruppen. Treningsgruppen hadde bedre selvrapportert hoftefunksjon, målt ved spørreskjemaet WOMAC, før protesekirurgi enn kontrollgruppen, men det var ingen forskjeller i selvrapportert smerte.

- Denne studien kan ha betydning for mange pasienter som med veiledet trening kan unngå eller utsette protesekirurgi, sier Ida Svege, som er førsteforfatter og doktorgradsstipendiat ved Norsk forskningssenter for aktiv rehabilitering. - Dermed kan også helsetjenestens kostnader ved protesekirurgi reduseres. For pasienter som har tolererbar smerte og som er i stand til å opprettholde sitt ønskede aktivitetsnivå, anser vi det å være hensiktsmessig å utsette en hofteproteseoperasjon.

Dette er den første studien der effekten av trening på behovet for hofteprotese er evaluert. Det er behov for flere studier for å bekrefte disse funnene, sier Svege.

\section{Norsk forskningssenter for aktiv rehabilitering}

Studien er resultat av et samarbeid mellom Norsk forskningssenter for aktiv rehabilitering og Ortopedisk avdeling ved Oslo universitetssykehus. Forskningssenteret ble etablert for ti år siden på tvers av tre ulike institusjoner: Ortopedisk avdeling ved Oslo universitetssykehus, Norsk idrettsmedisinsk institutt (NIMI) og Seksjon for idrettsmedisinske fag ved Norges idrettshøgskole. Forskningsgruppen ledes av professor og fysioterapeut May Arna Risberg. De forsker særlig på aktiv rehabilitering ved kneskader, kneartrose, hofteartrose og osteoporose.

Rehabiliteringsprogrammet for denne studien ble utviklet i nært samarbeid mellom forskere og klinikere ved Norsk idrettsmedisinsk institutt, hvor det i dag drives artroseskole og forskningsbasert aktiv rehabilitering for pasienter med artrose.

\section{Matilde Risopatron Berg \\ Tidsskriftet}

Litteratur
1. Svege I, Nordsletten L, Fernandes L et al. Exercise therapy may postpone total hip replacement surgery in patients with hip osteoarthritis: a longterm follow-up of a randomised trial. Ann Rheum Dis 2013. E-publisert 20.11.
Ordforklaringer

Hofteartrose: En degenerativ leddlidelse som $\varnothing$ delegger leddbrusken og omkringliggende vev og medfører endringer i bruskens strukturelle oppbygning og dens egenskaper. Dette kan gi leddsmerter og nedsatt funksjon.

Hofteprotese: Kirurgisk behandling som gis ved fremskreden artrose hvor acetabulum og caput femoris/øvre enden av femur erstattes av kunstige deler i metall, polyetylen eller keramikk.

WOMAC: Western Ontario and McMasters Universities Osteoarthritis Index er et sykdomsspesifikt, selvrapportert spørreskjema for evaluering av smerter, stivhet og funksjon hos pasienter med hofteartrose. 